\title{
HUBUNGAN ANTARA GAYA BELAJAR DAN JENIS KELAMIN TERHADAP HASIL BELAJAR MATEMATIKA
}

\author{
Ranindya Masyarah Gustiary ${ }^{1_{*}}$, Darsih Idayani ${ }^{2}$ \\ Program Studi Pendidikan Matematika STKIP PGRI Situbondo \\ *e-mail: ranindyafauzi11@gmail.com
}

\begin{abstract}
The purpose of this reseach was to determine the correlation between learning style and gender toward mathematics learning result of $8^{\text {th }}$ grade students at MTs Negeri 1 Situbondo, odd semester in academic year 2017/2018. The research method is quantitative with random sampling and Slovin formula is used to determine sample number. Data collection technique are documentation and questionnaire. The population of this study was 106 students with sample size of 84 . Hypothesis testing using Product Moment correlation, multiple correlations, and $F_{\text {test. }}$ The results of this research indicate that there is a correlation between learning style and learning result with $r_{\text {count }} 0,477>r_{\text {table }} 0,2146$. There is no correlation between gender and learning outcome with $r_{\text {count }} 0,209<r_{\text {tabel }} 0,2146$. There is a correlation between learning style and gender toward learning result with $\mathrm{R}_{\mathrm{YX} 1 \mathrm{X} 2}$ count $0,48504>\mathrm{r}_{\text {table }} 0,2146$. Compared with the table of multiple correlation coefficients, $\mathrm{R}_{\mathrm{YX} 1 \mathrm{X} 2}$ value of 0.48504 is at a moderate correlation level. At a significant level of $5 \%$ obtained result $F_{\text {table }} 3.11<F_{\text {count }} 12,459$. The alternative hypothesis is accepted. It indicates that the null hypothesis is rejected. There is a significant correlation between learning style and gender toward mathematics learning result of $8^{\text {th }}$ grade students at MTs Negeri 1 Situbondo academic year $2017 / 2018$.
\end{abstract}

\section{Keywords : Learning styles, Gender, Learning Outcomes, Correlation}

Abstrak: Penelitian ini mempunyai tujuan untuk mengetahui apakah ada hubungan atau tidak antara gaya belajar dan jenis kelamin terhadap hasil belajar matematika siswa kelas VIII semester ganji di MTs Negeri 1 Situbondo Tahun Pelajaran 2017/2018. Metode penelitian kuantitatif digunakan dalam penelitian ini dengan teknik pengambilan sampel menggunakan sampel acak dan penghitungan jumlah sampel menggunakan rumus Slovin. Untuk mengumpulkan data digunakan teknik dokumentasi dan angket. Jumlah populasi penelitian ini sebanyak 106 siswa dengan jumlah sampel sebanyak 84. Pengujian hipotesis menggunakan korelasi Product Moment, korelasi ganda, dan dilanjutkan dengan uji F. Hasil penelitian ini menunjukkan bahwa: (1) Ada hubungan antara gaya belajar dan hasil belajar dengan $r_{\text {hitung }} 0,477>r_{\text {tabel }} 0,2146$. (2) Tidak ada hubungan antara jenis kelamin dan hasil belajaar dengan $r_{\text {hitung }} 0,209<r_{\text {tabel }}$ 0,2146 (3) Ada hubungan antara gaya belajar dan jenis kelamin terhadap hasil belajar dengan RYX1X2 hitung 0,48504> $\mathrm{r}_{\text {tabel }}$ 0,2146. Dibandingkan dengan tabel koefisien korelasi berganda, nilai $\mathrm{R}_{\mathrm{YX} 1 \mathrm{X} 2}$ 0,48504 berada pada tingkat hubungan sedang. Pada taraf signifikan $5 \%$ diperoleh hasil $\mathrm{F}_{\text {tabel }} 3,11<\mathrm{F}_{\text {hitung }} 12,459$. Hipotesis alternatif $\left(\mathrm{H}_{\mathrm{a}}\right)$ diterima dan hipotesis nihil (Ho) ditolak, artinya ada hubungan yang signifikan antara gaya belajar dan jenis kelamin terhadap hasil belajar matematika siswa kelas VIII di MTs Negeri 1 Situbondo tahun pelajaran 2017/2018.

Kata kunci : Gaya belajar, Jenis kelamin, Hasil belajar, Hubungan

\section{PENDAHULUAN}


Belajar adalah suatu kata yang sudah akrab dengan semua lapisan masyarakat. Proses belajar selalu dialami oleh setiap individu dalam hidupnya. Perubahan akan terjadi dalam diri setiap individu melalui proses belajar tersebut. Perubahan tersebut antara lain menguasai kecakapan tertentu, perubahan sikap, memiliki ilmu pengetahuan yang berbeda dari sebelum melakukan proses pembelajaran. Perubahanperubahan ini adalah hasil dari tindakan belajar yang diinginkan. Oleh karena itu dapat dikatakan bahwa perubahan yang diinginkan akan menjadi tujuan proses pembelajaran.

Gaya belajar terdiri dari kata gaya dan belajar. Dalam Kamus Besar Bahasa Indonesia, gaya adalah tingkah laku, gerak-gerik, dan sikap (KBBI, 2018b). Sedangkan belajar menurut Kamus Besar Bahasa Indonesia adalah berusaha memperoleh kepandaian atau ilmu (KBBI, 2018a). Gaya belajar merupakan gabungan dari bagaimana siswa menyerap, menata, dan mengolah informasi yang diperoleh. Salah satu kunci keberhasilan siswa dalam belajar adalah gaya belajar yag sesuai dengan karakter siswa. Siswa akan dapat menyerap, mengolah informasi, dan menjadikan belajar lebih mudah dan menyenangkan jika belajar dengan gaya belajar siswa itu sendiri. Menurut Bobbi DePorter dan Mike Hernacki gaya belajar manusia secara umum dibedakan menjadi tiga kelompok, yaitu visual, auditorial, dan kinestetik (DePorter \& Hernacki, 2015).

Menggunakan gaya belajar yang terbatas dalam satu bentuk saja, misalnya yang bersifat auditorial atau verbal, dapat menyebabkan kesulitan dalam menyerap informasi yang diterima. Kenyataannya banyak siswa dengan hasil belajar yang rendah. Hal ini tercermin pada siswa yang tidak mengetahui dan memahami gaya belajarnya sendiri. Rendahnya ketidakpahaman siswa dengan gaya belajarnya sendiri sangat disayangkan, karena gaya belajar mempunyai peran yang sangat penting dalam meningkatkan hasil belajar dan kualitas belajar siswa laki-laki maupun siswa perempuan.

Terdapat dua golongan berdasarkan jenis kelamin yaitu laki-laki dan perempuan. Lakilaki dan perempuan memiliki perbedaan biologis, motorik, kognitif emosi, perilaku, dan kepribadian. Saat ini banyak orang yang belum bisa membedakan antara pengertian istilah jenis kelamin dan gender secara jelas. Hal tersebut menyebabkan kedua terminologi tersebut sering dianggap sama secara konseptual, padahal pengertian jenis kelamin dan gender sangat berbeda (Djunaedi \& Muzayyanah, 2008). Oleh sebab itu, 
sebelum membahas gender secara lebih lanjut ada hal penting yang harus dilakukan yaitu memahami perbedaan antara konsep gender dan seks (jenis kelamin). Kesalahan dalam memahami makna gender dapat menimbulkan sikap sulit menerima analisis gender dalam memecahkan masalah ketidakadilan sosial.

Menurut Mufidah Cholil, secara etimologis, gender berasal dari kata gender yang berarti jenis kelamin (Cholil, 2010). Tetapi gender berbeda dengan jenis kelamin yang tidak disebabkan oleh perbedaan biologis ataupun kodrat Tuhan, tetapi diciptakan melalui sosial budaya yang prosesnya panjang. Perbedaan tingkah laku antara laki-laki dan perempuan, selain karena faktor biologis, sebagian besar justru terjadi karena proses sosial dan kultural. Maka gender dapat berubah-ubah antara tempat satu ke tempat lain, waktu ke waktu, atau antar kelas sosial ekonomi masyarakat (Fakih, 2016). Jika dilihat dengan batas perbedaan yang paling sederhana, seks dapat dilihat sebagai status bawaan yang melekat sejak lahir, sedangkan gender dilihat sebagai status yang diterima atau diperoleh dari lingkungan.

Akan tetapi prestasi akademik siswa tidak dapat dijelaskan melalui perbedaan biologis. Penyebab dominan yang menyebabkan adanya perbedaan antara laki-laki dan perempuan dalam prestasi akademik adalah faktor sosial dan kultural. Hal-hal yang termasuk dalam faktor-faktor tersebut adalah familiaritas terhadap mata pelajaran, persepsi terhadap mata pelajaran, gaya belajar siswa, serta perlakuan guru.

Hasil belajar merupakan kemampuan yang didapatkan oleh siswa setelah melalui kegiatan belajar. Kegiatan belajar siswa dapat dilihat dari besarnya usaha siswa dalam belajar sehingga berpengaruh terhadap hasil belajarnya. Secara garis besar Benjamin Bloom dalam (Sudjana, 2017) membagi hasil belajar menjadi tiga ranah yaitu kognitif, afektif, dan psikomotorik. Hasil belajar matematika adalah perubahan perilaku secara keseluruhan yang dimiliki oleh siswa yang menjadi standar pencapaian indikator setelah menggunakan pengetahuannya tentang bilangan, bentuk, dan ukuran serta menggunakan hubungan-hubungan untuk membantu seseorang memahami dan menguasai permasalahan dalam kehidupan sehari-hari.

Dalam proses pembelajaran, sebenarnya perbedaan jenis kelamin tidak mempengaruhi hasil belajar siswa. Sebenarnya hal ini dapat dipengaruhi oleh perbedaan kognitif, fisik, self-esteem, motivasi, aspirasi karier, dan hubungan interpersonal. Perbedaan-perbedaan inilah yang menjadi patokan bagi guru untuk dapat menciptakan 
suasana kelas tanpa memperhatikan gender yang berbeda. Dengan kata lain perubahan proses pembelajaran matematika yang menyenangkan memperhatikan gaya belajar siswa, sehingga siswa laki-laki dan perempuan merasa nyaman, dan tidak cemas dalam pelajaran matematika.

Berdasarkan penjelasan di atas, diperlukan penelitian untuk mengetahui hubungan gaya belajar dan jenis kelamin terhadap hasil belajar matematika. Oleh karena itu penelitian ini berjudul Hubungan Gaya Belajar dan Jenis Kelamin Terhadap Hasil Belajar Matematika Siswa Kelas VIII Semester Ganjil di MTs Negeri 1 Situbondo Tahun Pelajaran 2017/2018.

\section{METODE}

Jenis penelitian ini adalah penelitian kuantitatif. Penelitian ini bersifat non eksperimental dengan menggunakan metode penelitian ex post facto. Penelitian ex post facto adalah penelitian yang bertujuan untuk menemukan penyebab yang mungkin menyebabkan perubahan perilaku, gejala atau fenomena yang disebabkan oleh suatu peristiwa, perilaku atau hal-hal yang menyebabkan perubahan pada variabel bebas yang secara keseluruhan sudah terjadi. Pemilihan lokasi dalam penelitian menggunakan metode Purposive Sampling Area. Dengan metode ini peneliti dengan sengaja menetapkan daerah penelitian pada suatu tempat tertentu tanpa ada pilihan tempat lain. Penelitian ini akan dilaksanakan di MTs Negeri 1 Situbondo pada bulan Mei 2018 sesuai dengan jadwal yang ditentukan. Dilaksanakan melalui beberapa tahapan sampai mendapatkan data yang valid.

Dalam menentukan jumlah sampel, Arikunto menyatakan apabila ukuran populasi lebih dari 100, sampel dapat diambil dari kisaran $10-15 \%, 20-25 \%$, atau lebih dari $25 \%$ (Arikunto, 2013). Berdasarkan teori-teori tersebut, maka sampel yang digunakan pada penelitian ini tergantung dari jumlah populasi siswa kelas VIII MTs Negeri 1 Situbondo. Besarnya sampel dalam penelitian ini ditentukan dengan rumus Slovin (Sugiyono, 2018), yaitu

$$
n=\frac{N}{1+N e^{2}}
$$

dimana: 
$n=$ jumlah sampel

$N=$ jumlah populasi

$e=$ error level (tingkat kesalahan)

Teknik pengumpulan data yang diguakan dalam penelitian ini adalah dokumentasi dan kuesioner (angket). Metode dokumentasi yang digunakan berupa data absen siswa kelas VIII dan data hasil belajar siswa yang diambil dari hasil ulangan tengah semester ganjil mata pelajaran kelas VIII. Menurut Sugiyono, kuesioner (angket) merupakan teknik pengumpulan data yang dilakukan dengan cara memberi beberapa pertanyaan atau pernyataan tertulis kepada responden untuk dijawab (Sugiyono, 2018). Kuesioner (angket) ini diberikan untuk mengetahui gaya belajar siswa. Dibuat dengan model skala likert yang mempunyai empat pilihan jawaban. Empat pilihan jawaban yang berjumlah genap ini dimaksudkan untuk menghindari kecenderungan responden bersikap ragu-ragu dan tidak mempunyai jawban yang jelas. Angket berisi 30 pernyataan diisi dengan memberikan tanda cecklist $(\sqrt{ })$ pada pilihan selalu (SL), sering (SR), kadang-kadang (KD), atau tidak pernah (TP).

Teknik analisis data yang digunakan dalam penelitian ini adalah analisis korelasi ganda (multiple corelation). Analisis korelasi ganda adalah analisis data statistik untuk mencari hubungan antara dua buah variabel atau lebih. Sebelum menganalis data, peneliti melakukan uji instrumen terlebih dahulu. Menurut Arikunto, instrumen yang baik harus memenuhi dua syarat yaitu valid dan reliabel. Validitas adalah ukuran yang menunjukkan tingkat-tingkat kevalidan atau kesahihan suatu instrumen. Suatu instrumen yang valid atau sahih mempunyai validitas tinggi, sebaliknya instrumen yang kurang vaild berarti memiliki validitas rendah (Arikunto, 2013). Validitas instrumen dapat diukur dengan angka kasar menggunakan metode Pearson Product Moment. Reliabilitas menunjuk pada satu pengertian bahwa sesuatu instrumen cukup dapat dipercaya untuk digunakan sebagai alat pengumpul data karena instrumen tersebut sudah baik. Reliabilitas menunjuk pada tingkat keterandalan sesuatu. Realiabel artinya dapat dipercaya, jadi dapat diandalkan. Instrumen yang sudah dapat dipercaya, yang reliabel akan menghasilkan data yang dapat dipercaya juga (Arikunto, 2013). Pengujian reliabilitas instrumen angket dalam penelitian ini adalah dengan meggunakan metode Alpha Cronbach's. 
Untuk mencari hubungan antara gaya belajar terhadap hasil belajar, dan hubungan antara jenis kelamin tehadap hasil belajar, menggunakan analisis korelasi sederhana. Uji korelasi sederhana digunakan untuk mengetahui seberapa erat hubungan antara dua variabel penelitian, dengan rumus korelasi Pearson Product Moment (Arikunto, 2013).

\section{HASIL DAN PEMBAHASAN}

\section{Hasil}

Untuk kelas VIII terdiri dari 7 kelas, kelas VIII A sampai VIII G. Dari tujuh kelas tersebut peneliti hanya mengambil 4 kelas untuk dijadikan obyek dari penelitian ini, atau disebut dengan populasi. Empat kelas itu adalah kelas VIII C, kelas VIII D, kelas VIII E, dan kelas VIII F yang ditentukan secara acak oleh peneliti. Diperoleh 106 siswa yang akan dijadikan obyek dan diambil sampel untuk dijadikan responden penelitian ini. Besarnya sampel ditentukan dengan rumus Slovin berikut ini.

$$
n=\frac{N}{1+N e^{2}}
$$

Maka:

$$
n=\frac{106}{1+106(0,05)^{2}}=\frac{106}{1,265}=83,7 \approx 84
$$

Jumlah sampel dalam penelitian ini adalah 84, sehingga dengan demikian peneliti mengambil 84 siswa dari jumlah populasi. Dengan jumlah masing-masing kelas yaitu kelas VIII C 18 siswa, kelas VIII D 19 siswa, kelas VIII E 23 siswa, kelas VIII F 24 siswa.

Pada data dokumentasi peneliti juga mendapatkan hasil belajar matematika siswa kelas VIII yang diambil dari nilai UTS semester ganjil tahun pelajaran 2017/2018. Nilai UTS yang diambil hanya nilai siswa kelas VIII C, kelas VIII D, kelas VIII E, dan kelas VIII F sebagai responden dalam penelitian ini. Nilai terbanyak yang diperoleh adalah $75-78$ dengan rata-rata 77,38. Peneliti membuat angket dengan model skala likert yang mempunyai 4 jawaban, terdiri dari 30 item. 30 item soal tersebut terbagi dalam 3 bagian materi yaitu materi gaya belajar visual, materi gaya belajar auditorial, dan materi gaya belajar kinestetik. Setiap item angket mempunyai alternatif jawaban dengan ketentuan sebagai berikut

a. Jawaban SL (Selalu) bernilai 4

b. Jawaban SR (Sering) bernilai 3 

c. Jawaban KD (Kadang-kadang) bernilai 2
d. Jawaban TP (Tidak Pernah) bernilai 1

Setelah siswa mengisi angket diperoleh data yang disajikan dalam Tabel 1 berikut ini.

\section{Tabel 1. Jumlah Siswa Masing-masing Gaya Belajar}

\begin{tabular}{|l|c|}
\hline Gaya Belajar & Banyak Siswa \\
\hline Visual & 42 \\
\hline Auditorial & 27 \\
\hline Kinestetik & 15 \\
\hline \multicolumn{1}{|c|}{ Jumlah } & 84 \\
\hline
\end{tabular}

Dari data diatas dapat diketahui bahwa gaya belajar yang paling dominan di kelas VIII C, kelas VIII D, kelas VIII E, dan kelas VIII F adalah gaya belajar visual. Ini terlihat dari jumlah siswa dengan gaya belajar visual di masing-masing kelas.

Uji validitas digunakan untuk mengetahui valid atau tidaknya item pernyataan pada angket. Untuk item pernyataan yang sudah dinyatakan valid akan digunakan dalam penelitian, sedangkan untuk item pernyataan yang tidak valid tidak akan digunakan dalam angket penelitian. Validitas instrumen menggunakan rumus Pearson Product Moment dibantu dengan SPSS Statistics 17.0.

Hasil dari analisis validitas angket dengan SPSS diperoleh 20 item valid yaitu item nomor 1, 4,5, 8, 12, 13, 14, 15, 16, 17, 18, 19, 21, 22, 23, 24, 25, 26, 29, dan 30 .

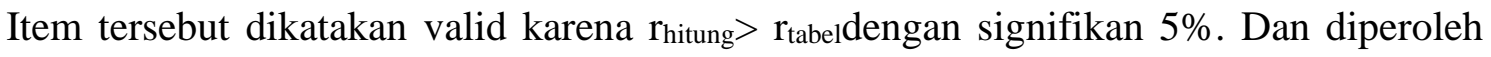
10 item yang tidak valid yaitu item nomor 2, 3, 6, 7, 9, 10, 11, 20, 27, dan 28 dikatan tidak valid karena $\mathrm{r}_{\text {hitung }}<\mathrm{r}_{\text {tabel }}$ dengan signifikan $5 \%$.

Dalam penelitian ini, dilakukan uji reliabilitas dengan menggunakan Alpha Cronbach dibantu dengan menggunakan SPSS Statistics 17.0. Dari hasil SPSS diperoleh hasil Alpha Cronbach sebesar 0,627. Jika dilihat dengan kriteria diatas dapat dsimpulkan bahwa instrumen penelitian yang digunakan cukup reliabel.

Pada bagian korelasi dilakukan perhitungan untuk mengetahui hubungan antara gaya belajar $\left(\mathrm{X}_{1}\right)$ terhadap hasil belajar $(\mathrm{Y})$, hubungan antara jenis kelamin $\left(\mathrm{X}_{2}\right)$ terhadap hasil belajar $(\mathrm{Y})$, dan hubungan antara gaya belajar $\left(\mathrm{X}_{1}\right)$ dan jenis kelamin $\left(\mathrm{X}_{2}\right)$ secara 
bersama-sama terhadap hasil belajar (Y) guna menjawab hipotesis. Perhitungan dilakukan dengan rumus Product Moment dengan angka kasar untuk mencari koefisien korelasi antar variabel, dilanjutkan dengan menghitung korelasi ganda (Arikunto, 2013).

Setelah uji analisis diperoleh $r_{x 1 y}>$ tabel $=0,47743>0,2146$, Ha diterima, artinya ada hubungan antara gaya belajar dan hasil belajar, $r_{\mathrm{x} 2 \mathrm{y}}<$ tabel $=0,20906<$ 0,2146, Ha ditolak, artinya tidak ada hubungan jenis kelamin dan hasil belajar, dan $\mathrm{R}_{\mathrm{YX} 1 \mathrm{X} 2}=0,48504$. Untuk melihat seberapa erat antara variabel $\mathrm{X}_{1}, \mathrm{X}_{2}$ bersama-sama terhadap Y, dilakukan uji signifikan koefisien korelasi berganda dengan menggunakan Uji F, diperoleh nilai 12,459.

\section{Pembahasan}

Penelitian dilakukan untuk mengatahui ada tidaknya hubungan antara gaya belajar dan jenis kelamin terhadap hasil belajar matematikan siswa kelas VIII di MTs Negeri 1 Situbondo. Pengumpulan data dilakukan dengan mengumpulkan data siswa seperti absensi siswa dan nilai UTS semester ganjil. Kemudian menyebarkan angket kepada siswa, dari hasil angket tersebut kita lakukan skoring dan ditabulasi sehingga dapat diketahui keadaan siswa dalam hal gaya belajar yang dimiliki.

Sebelum analisis data dilakukan uji validitas dan reliabilitas untuk mengetahui kebenaran dan kesesuaian instrumen yang digunakan. Dari hasil perhitungan diperoleh $\mathrm{r}_{\text {hitung }}>\mathrm{r}_{\text {tabel }}$, maka 20 item pada instrumen yang digunakan untuk pengumpulan data dengan penyebaran angket kepada siswa bernilai valid. Untuk menguji reliabilitas menggunakan program SPSS for Windows release 17.0, diperoleh nilai yang melebihi dari $r_{\text {tabel }}$ sehingga dapat disimpulkan bahwa instrumen yang digunakan sudah sesuai atau reliabel.

Setelah data diperoleh, dilanjutkan dengan mencari korelasi atau hubungan antar variabel menggunakan perhitungan korelasi dengan rumus Product Moment dan korelasi ganda sesuai dengan permasalahan yang diajukan. Yang pertama, mencari hubungan antara gaya belajar terhadap hasil belajar, diperoleh data $r_{x 1 y}>r_{\text {tabel }}=0,47743$ $>0,2146$. Dengan kondisi yang ada di lapangan gaya belajar yang dimiliki masingmasing siswa yang digunakan dalam proses pembelajaran metematika berperan penting untuk mendapatkan hasil belajar yang baik. Hal ini dapat diartikan adanya hubungan antara gaya belajar terhadap hasil belajar matematika. Yang kedua, mencari hubungan antara jenis kelamin terhadap hasil belajar, diperoleh data $r_{x 2 y}<r_{\text {tabel }}=0,20906<$ 
0,2146. Perbedaan jenis kelamin siswa tidak mempengaruhi hasil belajar itu sendiri, karena pada kenyataannya setiap siswa laki-laki maupun perempuan proses pembelajarnya sesuai dengan metode atau cara mengajar yang digunakan oleh guru. Artinya tidak ada hubungan antara jenis kelamin dan hasil belajar matematika. Setelah diketahui hubungan antara $\mathrm{X}_{1}$ terhadap $\mathrm{Y}$, dan hubungan antara $\mathrm{X}_{2}$ terhadap $\mathrm{Y}$, kita dapat mencari hubungan antara $\mathrm{X}_{1}, \mathrm{X}_{2}$ terhadap $\mathrm{Y}$ secara bersama-sama dengan menggunakan korelasi ganda. Diperoleh hasil RYX1X2 sebesar 0,48504.

Pada pengujian hipotesis $\mathrm{X}_{1}$ terhadap $\mathrm{Y}$ adalah ada hubungan yang cukup kuat anatar gaya belajar terhadap hasil belajar dilihat dari hasil $r_{x 1 y}>r_{\text {tabel }}=0,47743>$ 0,2146 yang kemudian dibandingkan dengan tabel interpretasi koefisien korelasi. Sedangkan untuk pengujian hipotesis $\mathrm{X}_{2}$ terhadap $\mathrm{Y}$ adalah ada hubungan yang rendah antara jenis kelamin terhadap hasil belajar dilihat dari hasil $r_{\mathrm{x} 2 \mathrm{y}}<r_{\text {tabel }}=0,20906<$ 0,2146 yang kemudian dibandingkan dengan tabel interpretasi koefisien korelasi.

Untuk mengetahui taraf keeratan antara variabel $\mathrm{X}_{1}, \mathrm{X}_{2}$, dan $\mathrm{Y}$ menggunakan Uji $\mathrm{F}$. Taraf keeratan akan diketahui apabila $F_{\text {hitung }}$ lebih besar dari $F_{\text {tabel }}\left(F_{\text {hitung }}>F_{\text {tabel }}\right)$ dengan taraf signifikan 5\%. Besar $F_{\text {hitung }}$ adalah 12,459 lebih besar dari $F_{\text {tabel }}$ yaitu 3,11 pada $\mathrm{N}=$ 84. Dan dari hasil perhitungan $R_{\text {hitung }}$ lebih besar dari $R_{\text {tabel }}\left(R_{\text {hitung }}>R_{\text {tabel }}\right)$ yaitu sebesar 0,48504 > 0,2146 yang kemudian dibandingkan dengan tabel koefisien korelasi. Dengan hipotesis yang telah diajukan yaitu :

1. Ho: Tidak ada hubungan antara gaya belajar dan jenis kelamin terhadap hasil belajar matematika kelas VIII di MTs Negeri 1 Situbondo.

2. Ha: Ada hubungan antara gaya belajar dan jenis kelamin terhadap hasil belajar matematika kelas VIII di MTs Negeri 1 Situbondo.

Dengan begitu hipotesis nihil (Ho) ditolak dan hipotesis alternatif (Ha) diterima, artinya ada hubungan antara gaya belajar dan jenis kelamin terhadap hasil belajar matematika siswa kelas VIII di MTs Negeri 1 Situbondo.

\section{SIMPULAN}

Dari hasil penilitian, jenis gaya belajar yang paling dominan di kelas VIII adalah gaya belajar visual. Dan kesimpulan dalam penelitian ini adalah

1. Ada hubungan yang antara gaya belajar terhadap hasil belajar matematika siswa kelas VIII semester ganjil di MTs Negeri 1 Situbondo. 
2. Tidak ada hubungan antara jenis kelamin terhadap hasil belajar matematika siswa kelas VIII semester ganjil di MTs Negeri 1 Situbondo.

3. Ada hubungan antara gaya belajar dan jenis kelamin terhadap hasil belajar matematika siswa kelas VIII semester ganjil di MTs Negeri 1 Situbondo.

\section{DAFTAR PUSTAKA}

Arikunto, S. (2013). Prosedur Penelitian : Suatu Pendekatan Praktik (Edisi Revisi). In Jakarta: Rineka Cipta.

Cholil, M. (2010). Bingkai Sosial Gender: Islam, Strukturasi dan Konstruksi Sosial. In Malang: UIN-Maliki Press. Malang: UIN-Maliki Press.

DePorter, B., \& Hernacki, M. (2015). Quantum learning: Membiasakan Belajar Nyaman dan Menyenangkan. In Bandung: Kaifa.

Djunaedi, W., \& Muzayyanah, I. (2008). Pendidikan Islam Adil Gender di Madrasah. In Jakarta: Pustaka STAINU.

Fakih, M. (2016). Analisis Gender dan Transformasi Sosial. In Yogyakarta: INSIST Press.

KBBI. (2018a). Arti Kata Belajar - Kamus Besar bahasa Indonesia (KBBI) Daring. Retrieved July 17, 2018, from Kementerian Pendidikan dan Kebudayaan Republik Indonesia website: https://kbbi.kemdikbud.go.id/entri/belajar

KBBI. (2018b). Arti Kata Gaya - Kamus Besar Bahasa Indonesia (KBBI) Daring. Retrieved July 17, 2018, from Kementerian Pendidikan dan Kebudayaan Republik Indonesia website: https://kbbi.kemdikbud.go.id/entri/gaya

Sudjana, N. (2017). Penilaian Hasil Proses Belajar Mengajar. In Bandung: PT. Remaja Rosdakarya.

Sugiyono. (2018). Metodologi Penelitian Kuantitatif, Kualitatif, dan R\&D. In Bandung: Alfabeta. 